\title{
Article \\ Gold Mining in the Amazon Region of Ecuador: History and a Review of Its Socio-Environmental Impacts
}

\author{
Carlos Mestanza-Ramón ${ }^{1,2, *(\mathbb{D}}$, Jefferson Cuenca-Cumbicus ${ }^{3}$, Giovanni D’Orio ${ }^{4}{ }^{(\mathbb{D}}$, Jeniffer Flores-Toala ${ }^{5}$, \\ Susana Segovia-Cáceres ${ }^{6}$, Amanda Bonilla-Bonilla ${ }^{5}$ and Salvatore Straface ${ }^{1}$ (i) \\ 1 Department of Environmental Engineering, University of Calabria, 87036 Rende, Italy; \\ salvatore.straface@unical.it \\ 2 Research Group YASUNI-SDC, Escuela Superior Politécnica de Chimborazo, Sede Orellana, \\ El Coca 20001, Ecuador \\ 3 Green Amazon, Research Center, Nueva Loja 210150, Ecuador; jefferson.cuenca@espoch.edu.ec \\ 4 Department of Economics, Statistics and Finance, University of Calabria, 87036 Arcavacata di Rende, Italy; \\ giovanni.dorio@unical.it \\ 5 Escuela Superior Politécnica de Chimborazo, Sede Orellana, El Coca 220001, Ecuador; \\ jeniffer.flores@espoch.edu.ec (J.F.-T.); amanda.bonilla@espoch.edu.ec (A.B.-B.) \\ 6 Escuela Superior Politécnica de Chimborazo, Sede Morona Santiago, M. Santiago 140105, Ecuador; \\ susana.segovia@espoch.edu.ec \\ * Correspondence: cmestanza@ug.uchile.cl
}

Citation: Mestanza-Ramón, C.; Cuenca-Cumbicus, J.; D’Orio, G.; Flores-Toala, J.; Segovia-Cáceres, S.; Bonilla-Bonilla, A.; Straface, S. Gold Mining in the Amazon Region of Ecuador: History and a Review of Its Socio-Environmental Impacts. Land 2022, 11, 221. https://doi.org/ 10.3390/land11020221

Academic Editor: Alberto Matarán Ruiz

Received: 31 December 2021

Accepted: 30 January 2022

Published: 1 February 2022

Publisher's Note: MDPI stays neutral with regard to jurisdictional claims in published maps and institutional affiliations.

Copyright: (C) 2022 by the authors. Licensee MDPI, Basel, Switzerland. This article is an open access article distributed under the terms and conditions of the Creative Commons Attribution (CC BY) license (https:// creativecommons.org/licenses/by/ $4.0 /)$

\begin{abstract}
Artisanal and small-scale gold mining (ASGM) and large-scale mining in the Ecuadorian Amazon region is potentially harmful to nature, and its impacts are associated with environmental degradation and deterioration of people's health. So far, limited efforts have been directed at exploring the current situation and challenges facing the implementation of environmental policies in the country. The objective of this study focused on analyzing the historical and current situation and challenges of ASGM in the Amazon region of Ecuador in relation to a political perspective (laws), socioeconomic impacts (population displacement, loss of livelihoods, migration of people, cost of living, water scarcity, and health impacts), and environmental impacts (biotic and abiotic). The methodology used was based on a literature review and interviews, and information that was discussed through an expert judgment allowed for establishing challenges to improve ASGM management. The main results indicate that lack of community participation in decision-making, insufficient coordination between government institutions, communities, and miners, and lack of control of mining activities are factors that contribute to ineffective compliance with environmental policies in the gold mining sector in the Amazon. Finally, the study concludes by considering the socioeconomic and environmental scopes within its findings for implementing effective environmental and social policies in the Amazon region of Ecuador.
\end{abstract}

Keywords: mercury; gold; socio-environmental impacts; environmental management; political management; environmental management

\section{Introduction}

Mining is the most important primary source of metals and minerals in the world [1,2]. Millions of people in developing countries depend on artisanal and small-scale gold mining (ASGM) for their livelihoods. However, this activity comes at a price $[3,4]$. These activities are quite diverse, sometimes illegal or informal, often virtually tolerated by the authorities, and can be seasonal or year-round, long-term, or follow a boom-and-bust cycle. Gold mining has a significant impact on the local climate, the natural environment, and the socioeconomic conditions of local residents. Mining activities and their methods of disposal of toxic by-products are considered one of the main reasons for the deterioration of environmental health [5-7]. ASGM is associated with many occupational and environmental health problems, especially when practiced informally or with limited material 
and technical resources. Gold mining extraction and processing activities release toxic substances such as mercury $(\mathrm{Hg})$, chromium $(\mathrm{Cr})$, cadmium $(\mathrm{Cd})$, and copper $(\mathrm{Cu})$ into the environment [8]. The health and well-being of miners, their families, as well as nearby communities are often adversely affected.

ASGM involves a complex interplay of social, economic, technological, environmental, and health factors that can vary considerably depending on the local and national context $[9,10]$. Such complexity makes it difficult to establish uniform definitions. ASGM is defined in the Minamata Convention on Mercury as "gold mining carried out by individual miners or small companies with limited production and capital investment" [11]. Most definitions of artisanal and small-scale mining share the following characteristics: an informal work sector, limited use of mechanical tools, labor-intensive work, low capital and productivity, exploitation of deposits, and limited access to land and markets. Artisanal and small-scale gold mining is carried out in more than 70 countries by approximately 10 to 15 million miners, including 4 to 5 million women and children. Although ASGM activities occur worldwide, they are most prevalent in South America, Africa, and Asia [12,13].

In Ecuador, gold mining activities originated before the conquest (activities carried out by the Incas). The arrival of the Spaniards, at the beginning of the 16th century, brought with it a frantic search for the metal and the opening of many gold mines, the main ones being those of Zaruma and Santa Barbara in the Southern Highlands and Nambija on the Amazonian slope. Gold and silver mining constituted the axis of the economy of the Audiencia of Quito until the middle of the 17th century, when, due to lack of political support, it declined in favor of the textile industry, cattle raising, and agriculture [14]. Over time, mining has come to play an important role in the economic growth and sustainable development of the country. History shows that there have been constant social struggles between indigenous movements and representatives of transnational corporations and government authorities in claiming their legitimate rights, such as free and informed citizen participation, guaranteed land tenure, and their self-definition as indigenous peoples and nationalities, which, according to Convention 169 of the International Labor Organization (ILO), guarantees collective human rights in the presence of mining projects carried out within the area they inhabit $[15,16]$.

The increase of mining activities in the Ecuadorian gold sector has placed natural resources under analysis in both academic and social spaces [17]. Exploration and exploitation activities are generally carried out against the will of the neighboring communities, which has caused social problems such as eviction of inhabitants from their properties and community discontent due to continuous environmental contamination, among others [18]. Artisanal and large-scale gold mining can negatively affect the environment (health risks, change land use, and livelihood options) and cause serious impacts for miners and surrounding communities, causing conflicts over land ownership and use $[19,20]$. Despite all this, the miner takes the risks and works with the well-being and daily needs of his family in mind [21-23].

The Ecuadorian Amazon has historically been known for its oil exploitation, but in recent decades mining activities have increased mainly in the northern zone in the provinces of Sucumbíos, Orellana, and Napo and in the southern zone in the provinces of Morona Santiago and Zamora Chinchipe. Thus, oil and gold mining activities are currently the major sources of contamination by metallic residues or by-products [24,25]. The large deposits of metamorphic gold in the Amazon are found in the southwest of Zamora Chinchipe, in the border area with Peru $[17,26,27]$. The mining areas of Nambija and Chinapintza are located in this area and are one of the most important mining areas for their production in Ecuador [28-30].

Currently, ASGM activities in developing countries are taking on greater interest in poor communities and areas [31-33]. This is no different in Ecuador, but it is important to highlight that these activities, such as all anthropic activities, generate an impact, with the difference being that the extraction of this precious material uses highly polluting elements such as Mercury (HG) and Cyanide (CN) that affect the atmosphere, water bodies, and soil. 
In addition, few studies have been developed to understand the history and situation of ASGM and its socioeconomic and environmental impact in the Amazonian area of Ecuador, limiting the proposal of alternative solutions to the problems of this economic activity. Given this, the objective of this study was to analyze the historical and current situation and challenges of artisanal small-scale and large gold mining (ASLGM) in the Amazon region of Ecuador from different perspectives, including policy (laws), socioeconomic impact (population displacement, loss of livelihoods, changes in population dynamics, cost of living, water scarcity, and health effects), and environment (biotic and abiotic) with a focus on $\mathrm{Hg}$. The methodology used was based on a literature review, interviews, field observation, and a very simple and practical technique called "expert judgment" carried out by people experienced in mining issues together with the researchers of this study with the purpose of establishing the final recommendations aimed at strengthening the management of gold mining in Ecuador.

\section{Materials and Methods}

\subsection{Study Area}

Ecuador, with a territorial extension of $270,670 \mathrm{~km}^{2}$, is located in the tropical zone on the northwestern coast of South America. It has 17.5 million inhabitants, of which $739,754,000$ live in the Amazonian provinces [34]. This region is made up of six provinces: Sucumbíos, Napo, Orellana, Pastaza, Morona Santiago, and Zamora Chinchipe (Figure 1). The present research focuses on the study of the ASLGM of the Ecuadorian Amazon. The cantons (type of administrative division of a country) of each province that registered gold as part of their mining activity were studied [35,36]. Mining concessions that are in the process of being processed have been discarded.
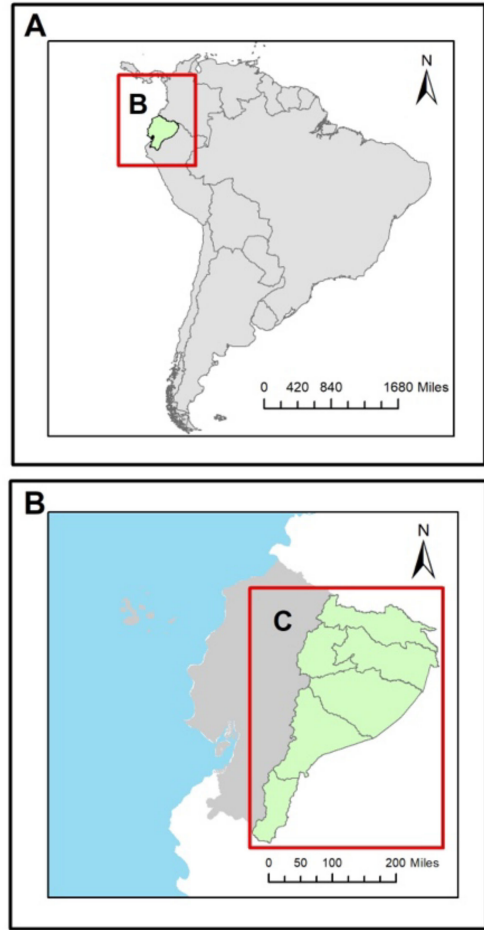

Figure 1. Study area: (A) Geographical location of Ecuador; (B) Amazon region of Ecuador; (C) provinces belonging to the Amazon region.

Although it is expected that, at present, gold mining in Ecuador represents at most $4 \%$, its socioeconomic and environmental analysis is relevant because of the impact on local communities in economic matters, as they see it as a source of subsistence and the pollution problems caused by the use of hazardous chemicals in their extractive processes. 
The provinces and cantons in which there is most legal and illegal gold mining activity have been considered, and data were obtained from the Geoportal of the Mining Cadastre in the Republic of Ecuador (Table 1) [37].

Table 1. Registered gold mining concessions in Ecuador's Amazon region.

\begin{tabular}{|c|c|c|c|c|c|c|c|c|}
\hline \multirow[b]{2}{*}{ No } & \multirow{2}{*}{ Province $^{1}$} & \multirow{2}{*}{ Canton $^{2}$} & \multicolumn{5}{|c|}{ Type of Application or Regime } & \multirow[b]{2}{*}{ Tota } \\
\hline & & & $\begin{array}{l}\text { General } \\
\text { Regime }\end{array}$ & $\begin{array}{l}\text { Large-Scale } \\
\text { Mining }\end{array}$ & $\begin{array}{c}\text { Medium } \\
\text { Mining }\end{array}$ & Small Mining & $\begin{array}{c}\text { Artisanal } \\
\text { Mining }\end{array}$ & \\
\hline \multirow{5}{*}{1} & \multirow{4}{*}{ Sucumbíos } & Gonzalo Pizarro & - & - & 1 & 4 & 6 & 11 \\
\hline & & Sucumbíos & - & 5 & 1 & 9 & 1 & 16 \\
\hline & & Cáscales & - & - & 1 & 3 & 18 & 22 \\
\hline & & Lago Agrio & - & - & - & 2 & 3 & 5 \\
\hline & & Subtotal & - & 5 & 3 & 18 & 28 & 54 \\
\hline \multirow{4}{*}{2} & \multirow{4}{*}{ Napo } & Tena & - & - & - & 16 & 69 & 85 \\
\hline & & El Chaco & 2 & - & - & 5 & - & 7 \\
\hline & & Carlos Julio Arosemena & 3 & - & - & 16 & 13 & 32 \\
\hline & & Subtotal & 5 & - & - & 37 & 82 & 124 \\
\hline \multirow{2}{*}{3} & \multirow{2}{*}{ Orellana } & Orellana & - & - & - & 1 & 2 & 3 \\
\hline & & Loreto & 1 & - & - & 1 & - & 2 \\
\hline & & Subtotal & 1 & - & - & 2 & 2 & 5 \\
\hline \multirow{3}{*}{4} & \multirow{3}{*}{ Pastaza } & Arajuno & - & - & - & - & 2 & 2 \\
\hline & & Pastaza & - & - & - & 1 & - & 1 \\
\hline & & Subtotal & - & - & - & 1 & 2 & 3 \\
\hline \multirow{9}{*}{5} & \multirow{9}{*}{$\begin{array}{l}\text { Morona } \\
\text { Santiago }\end{array}$} & Gualaquiza & 3 & 7 & 4 & 6 & 66 & 86 \\
\hline & & Limón Indanza & - & 21 & - & 3 & 16 & 40 \\
\hline & & Santiago & - & 5 & - & 5 & 69 & 79 \\
\hline & & Tiwintza & - & 3 & - & 10 & 28 & 41 \\
\hline & & Logroño & - & 18 & - & - & - & 18 \\
\hline & & Morona & 1 & 16 & - & 2 & 1 & 20 \\
\hline & & Palora & - & - & - & 1 & 28 & 29 \\
\hline & & San Juan Bosco & - & 3 & - & 2 & 2 & 7 \\
\hline & & Subtotal & 4 & 73 & 4 & 29 & 210 & 320 \\
\hline \multirow{10}{*}{6} & \multirow{10}{*}{$\begin{array}{l}\text { Zamora } \\
\text { Chinchipe }\end{array}$} & Zamora & - & 7 & - & 39 & 232 & 278 \\
\hline & & Yacuambi & - & 10 & - & 5 & 80 & 95 \\
\hline & & Paquisha & 1 & 2 & - & 25 & 42 & 70 \\
\hline & & El Pangui & - & 5 & - & 9 & 37 & 51 \\
\hline & & Nangaritza & 1 & 5 & - & 23 & 56 & 85 \\
\hline & & Chinchipe & - & 3 & 4 & 28 & 167 & 202 \\
\hline & & Palanda & - & 7 & - & 14 & 60 & 81 \\
\hline & & Yantzaza & - & 11 & 1 & 12 & 36 & 60 \\
\hline & & Centinela del Condor & - & 4 & - & 9 & 21 & 34 \\
\hline & & Subtotal & 2 & 54 & 5 & 164 & 731 & 956 \\
\hline
\end{tabular}

General regime: mining permits with old laws, which are currently in the process of being updated according to the new regulations; Small mining: in terms of production capacity, small mining is allowed to exploit up to 300 tons per day in subway mining, up to 1000 tons per day in open pit mining, and up to 1500 cubic meters per day in alluvial mining; Artisanal mining: activity carried out in free zones for survival purposes, not exceeding 4 hectares in subway conditions and 6 hectares in open pit conditions. Medium-scale mining: mining ranging from 301 to $1000 \mathrm{mt}$ per day in subway conditions, 1001 to $2000 \mathrm{mt}$ per day in open pit, and 1501 to $3000 \mathrm{~m}^{3}$ in alluvial mining; Large-scale mining: activity that exceeds all the maximum volumes described for medium-scale mining. ${ }^{1}$ The political division of Ecuador begins with regions (4: Coast, Highlands, Amazon, and Insular) and each region is made up of provinces. ${ }^{2}$ The union of cantons make up a province.

\subsection{Methods}

For a better understanding, the methodological process was divided into three subsections. In the first section, an exhaustive bibliographic review was applied to answer the 
first objective of the study on the historical situation regarding gold mining in aspects such as its policies, laws, and relevant socio-environmental impacts. In the second section, a semi-structured interview was applied to social actors related to gold mining activities in the Amazonian provinces to extract information concerning socioeconomic (population displacement, loss of livelihoods, migration of people, cost of living, water scarcity, and health effects) and environmental (biotic and abiotic) aspects, and as a last step, an expert judgment technique was applied to establish challenges for the continuous improvement of management in the field of gold mining focused on the aspects studied.

\subsubsection{Historical Situation: Literature Review}

In order to respond to the historical situation of ASGM, a systematic literature review was carried out, in which the content of the documents selected for analysis was reviewed. The methodological process in this first section was based on the search for information from scientific publications, corresponding to the last twenty years (2002-2021) in high impact databases such as Scopus and Web of Science; additionally, the search was complemented in regional databases such as Scielo and Redalyc. In the search process, filters were applied to establish the years of the publications; likewise, combinations of parameters were established in the search (Table 2), with the use of keywords in both English and Spanish by means of a parameterized advanced search.

Table 2. Search process and most relevant results of the literature review.

\begin{tabular}{|c|c|c|}
\hline Topic & Search Parameters & $\begin{array}{c}\text { Web of Science, Scopus, } \\
\text { and Regionals }\end{array}$ \\
\hline \multirow{3}{*}{$\begin{array}{l}\text { Historical situation of gold } \\
\text { mining in the Amazonian } \\
\text { region of Ecuador }\end{array}$} & "Gold" and "mining" and "Ecuador" and "Amazon" & $\begin{array}{c}7 \\
{[13,38-43]}\end{array}$ \\
\hline & "Gold" and "mining" and "Hg" and "Ecuador" and "Amazon" & $\begin{array}{c}4 \\
{[44-47]}\end{array}$ \\
\hline & $\begin{array}{l}\text { "Gold mining" +"Amazon" +"mercury exposure" + } \\
\text { "Ecuadorian Amazon" }\end{array}$ & $\begin{array}{c}4 \\
{[48-51]}\end{array}$ \\
\hline
\end{tabular}

Once the search results were obtained with their respective filters, 46 documents were obtained, which were subjected to an analysis of their titles, keywords, and abstracts to carry out a selection process to select only the documents relevant to the objective under study in the last 20 years and to discard the documents that were not considered relevant or were repeated because they were indexed in the different search databases. Finally, ten documents were selected after applying the filter. Likewise, the analysis of the bibliographic resources of the database (Table 2) was complemented with a gray bibliography (Table 3); this segment corresponds to a set of documents of various types, which have not undergone revision or editing processes, and are available in non-conventional channels. The documents selected were laws, the constitution, and regulations.

Table 3. Gray literature for the historical status of gold mining.

\begin{tabular}{cc}
\hline Gray Literature & Date of Creation \\
\hline Mining Law & Official Gazette Supplement 517 of \\
29 January 2009
\end{tabular}

\subsubsection{Current Situation: Field Interviews}

To describe the current situation, semi-structured interviews were conducted with the participation of key actors in the mining sector of the Ecuadorian Amazon. Face- 
to-face interviews were preferred with a duration of 30 to $60 \mathrm{~min}$, which facilitated the understanding of the reality of gold mining in the Amazon region of Ecuador. The strength of the tool used was its ability to uncover a wide variety of political, socioeconomic, and environmental factors potentially related to this economic activity that may not be known beforehand. The majority of interviewees were people affected by mining, with a variety of pro, anti, and neutral voices from each area. Interviews were conducted with a total of 154 people, including local miners, local authorities, national government representatives in the provinces studied, and residents of mining towns (Table 4). In addition, field observations were made in the areas visited by the research team. This important information collected helped to identify the current situation of gold mining in the Amazonian area of Ecuador, focusing on aspects such as the displacement of people, loss of livelihoods, migration of people, cost of living, water scarcity, and health impacts.

Table 4. Participants and key questions to understand the current situation of gold mining in the Amazon region.

\section{Participant}

Local miner/Association representative (48 interviewees, mining concession owner)

Local authority (48 interviewees, political leaders in the mining area)
What type of mining is developed?

Do you have a permit to carry out mining activities?

What type of technique is used for gold extraction, amalgamation or cyanidation? Is wastewater in the extraction process subjected to some treatment process prior to its environmental discharge?

Do you as a miner use any procedures to mitigate the impacts of gold mining? State three elements/components of the environment that are most affected by pollution.

Over the years, do you think there has been a shortage of water?

In your jurisdiction, have ordinances been created to control and monitor mining activities?

Do you know if there is illegal gold mining in your canton and/or parishes? Do you know if the inhabitants of your canton and/or parishes have had health problems associated with gold mining?

Do you know if gold mining is developed in your province?

Do you know if illegal gold mining is taking place in your province?

Have there been reports of contamination from gold mining?

How has the Environmental Authority developed audits of gold mining

concessions (rights)?

How has the Environmental Authority developed water monitoring in the water

bodies in the mining influence zone?

During the visits and/or audits, has the accumulation of mining waste

been evidenced?

Do you consider that leaching occurs in the residual accumulations?

Do you consider that gold mining has improved the quality of life in the area?

Does your monthly income cover all monthly expenses?

Has gold mining caused population displacement for any reason?

Has gold mining resulted in the loss of livelihoods?

Has the cost of living changed since the advent of gold mining?

Do you consider that, with gold mining activity, there is a shortage of water for daily activities?

Have any family members or acquaintances experienced health problems or death due to gold mining contamination?
(48 interviewees, community representatives per canton)

Finally, the information obtained from the literature review, interviews, and field observations was used to establish ASLGM challenges to improve strategic aspects of socioeconomic, political, and environmental management, through a process called expert judgment. This process made it possible to verify the reliability of the information obtained in the systematic review process and interviews. The experts who participated were spe- 
cialists in mining issues, management, and environmental authorities. These professionals discussed the main challenges facing the ASLGM in the Ecuadorian Amazon.

\section{Results}

Once the objectives had been established regarding the environmental impacts, human health problems and socioeconomic conflicts caused by ASGLM activities and emerging large-scale mining in the Amazon region of Ecuador were addressed. Likewise, once the methodological process in the previous section has been clearly and precisely established, it allowed for a response to the proposed objectives, giving rise to a set of results that are presented below. Thus, for a better understanding, the political-legal aspects, socioeconomic impacts (population displacement, loss of livelihoods, migration of people, cost of living, water scarcity, and health effects), and environmental aspects (biotic and abiotic) are described, with a historical and current approach. Finally, the present challenges in gold mining in the Amazon region on mining policy, the socioeconomic sector, and the environmental aspect are presented.

\subsection{A Review of the Political-Legal Evolution of Gold Mining in the Amazon Region}

Mining in Ecuador dates back to pre-Columbian times, has developed since colonial times, and has become very important in recent years [46]. The first mining regulations in Ecuador date back to colonial times when the Mining Ordinance of New Spain was enacted in 1753, which established that the Spanish Crown had the exclusive right to exploit mines. In 1829, Bolivar's Decree (Bolivar: Venezuelan politician, founder of the republics of Gran Colombia and Bolivia) determined that "mines of any kind correspond to the Republic, whose government grants them in property and possession to the citizens who request them", opening the possibility for mines to be concessioned [47]. Subsequently, the Mining Code of Ecuador of 1869 and its reform of 1892 ratified the state domain over the subsoil, the payment of an annual patent, reintroduced royalties as a precondition to keep the mining concession, and established surface easements to facilitate mining activities and the exemption of all taxes for 25 years. These regulations granted free prospecting to private individuals, as long as they paid the legal fees, which attracted foreign investors interested in exploring gold deposits [43,47].

Metal mining in Ecuador has historically been small-scale and artisanal, mostly concentrated in the south of the country. Ecuador's mining legislation was correspondingly rudimentary and was defined starting in 1937, when a law was sought to designate subsoil metals as state property. In the 1970s, a large mineral deposit was discovered in the south of the Ecuadorian Amazon, the Nambija mine in Zamora Chinchipe. Subsequently, in 1974, the Mining Development Law was enacted, which established that the mines belonged to the State and were inalienable and imprescriptible. In the same year, the Mining Development Law was enacted, which ratified state ownership of the subsoil and metals and established the necessary characteristics to be considered as entrepreneurial mining, small mining, and alluvial mining, but in 11 years of application of this law, there was no adequate development of the sector [52].

In 1985, the Mining Development Law was repealed and the Mining Law was passed, which ratified the inalienable and imprescriptible domain of mining deposits; the Ecuadorian Mining Institute (INEMIN) was created to be in charge of mining policy in the country, and royalties ranging from $1 \%$ to $3 \%$ were established for the State, the concession system and mining rights were regulated, a series of tax incentives were created, and the definition of small mining was eliminated, among other changes [46].

Mining-specific environmental legislation was absent in Ecuador until new laws came into effect in 1991. This legislation limited the granting of concessions on protected lands and required environmental impact assessments for all mining activities. In 1994, the World Bank funded the Mining Development and Environmental Control Project with the objective of developing the Ecuadorian mining sector [53]. The project collected mineralogical information from 3.6 million hectares of most of western Ecuador, including 
seven protected regions. The project's regulatory recommendations were codified into law in 2000, identifying mining as a national priority, and significantly deregulated the sector [45]. However, under the renewed regulations, mining development remained prohibited in government protected areas [43].

In the historical context, the legal framework of the Ecuadorian State sought to develop technologies to improve gold extraction and mining development through the Mining Law and other public policies with social and environmental responsibility [44]. In 2008, the Ecuadorian Constitution created a new legal framework with the objective of regulating mining activities [54]. It established that those who explore mineral resources must recover and conserve a healthy environment that guarantees the quality of water, air, and soil for people. It also established mechanisms for the prevention and control of environmental pollution and sustainable management of natural resources [55]. In this sense, illegal mining activities that affect biodiversity will be sanctioned in accordance with these laws [56,57].

The Mining Regulation and Control Agency established that it must audit, supervise, intervene, control, and sanction in all phases of mining activities, in accordance with the provisions of the Mining Law and the General Regulations to the Mining Law [54,56]. Although, in all phases of the mining activity, the obligation of environmental remediation and remediation is implicit in accordance with the Constitution of the Republic of Ecuador, the law and its regulations [54-56]. In the case of the Ecuadorian Amazon, it was established that the Municipal and Metropolitan Governments must regularize, authorize, and control mining exploitation in aquatic ecosystems $[55,56]$. They must observe and comply with the principles, rights, and obligations contemplated in the municipal ordinances and not allow conditions and obligations different from those established in the Mining Law and its regulations [57].

When talking about mining, the first legal institution to refer to is the 2008 Constitution of the Republic of Ecuador; however, this activity is regulated by specific legal institutions: the Mining Laws of 1991 and 2009; general norms related to the law: General Mining Law of October 1991, General Regulations of the Mining Law of 2001, Mining Rights of April 2008, and General Regulations of the Mining Law of November 2009. These political (legal) changes allowed institutions such as the Ministry of Mines and Energy and affiliates to work together to design and agree on an industry strategic plan to eliminate the use of $\mathrm{Hg}$ in mining [58]. The Mining Law establishes procedures, standards, and guidelines for the management of this department to minimize the adverse impact of mining exploration on the environment. In addition, it has also formulated norms for the transformation of mineral resources, which generate environmental, economic, and social benefit and protect the rights of miners, the country, and society [59]. Despite the mining law, they are to ensure the sustainable development of the activities, but due to the lack of a complete legislation and the imperfect applicability of the law, there are shortcomings.

The Ecuadorian Constitution establishes norms and general guidelines for the activities [55]. In addition, there is the Mining Law [59] and its updates, which are special laws that control the sector. Important changes occurred with the adoption of Ecuador's new constitution in 2008, which included the Mining Mandate that reverted most mining concessions to state ownership. The new law also allows mining in protected areas upon special request by the president and approval by the National Assembly. In 2009, the government of Rafael Correa drafted a new mining law that increased oversight of mining companies. Although the law has raised some environmental standards, indigenous and social movements have held widespread protests, hoping for greater environmental and social protection. In 2015 and 2016, the Correa government made deregulatory changes to the mining law to encourage foreign investment. These changes included lower corporate tax rates and special income taxes for mining companies. This greatly facilitated the acquisition of mining concessions, which led to the bidding and auctioning of state mining concessions that year and to an increase in the number of concessions granted recently [51].

The Ecuadorian Constitution establishes that, although all non-renewable natural resources are a strategic sector whose management and regulation is the responsibility of 
the government (art. 313), communities must be consulted prior to the establishment of extractive projects (art. 400) and must be granted the right to oppose (art. 98). However, the Ecuadorian Mining Law stipulates that communities living within mining concessions must only be consulted after the exploration license is granted, and the agreement of landowners and communities is not required to move forward with the development of mineral resources. Generally, there is no contract between the landowner and the miner, so the landowner is forced to illegally exploit his own land or enter into an informal agreement with the concessionaire. The Mining Law and the Special Regulations for Artisanal and Small-Scale Mining state that in situations where land is considered to be of "public utility," the government has the authority to allow mineral exploration and development, even if mining may interfere with communal access to quality food and water (Special Regulations art. 14; Mining Law art. 15; 28). In addition, the Mining Law also provides that sanctions may be imposed on individuals or groups that seek to disrupt or impede the development of mining activities (art. 100).

The lack of agreement between landowners and communities living within mining concessions represents a challenge for mining law in regulating the accessibility of mineral resources, community planning, the rights of individuals and communities, and economic development. Lack of monitoring and oversight by regulatory institutions (Table 5) generate environmental contamination [60]. Effective monitoring and regulatory mechanisms should be implemented to prevent illegal dumping of toxic substances. The implementation of corrective measures for environmental impacts should also be required in a timely manner. The legislation does not make an exception for illegal miners in terms of remediation. However, the authorities have not enforced it.

The literature review [61] and field research identified different reports and illegal mining activities (Table 6). In particular, illegal gold mining has increased exponentially in recent years. In 2016, it was estimated that around 77\% of Ecuador's gold production was extracted illegally. Of course, these numbers are now increasing (Table 6). Illegal gold mining has also been exponentially exposed in recent years [62]. Uncontrolled illegal gold mining is one of the main threats to biodiversity areas, which have unique species and are in danger of extinction. The Ecuadorian government has not prioritized the needs of its residents. These activities turned forests into deserts and exposed biodiversity and communities to $\mathrm{Hg}$. In addition, occasionally, these activities cause enormous environmental damage and land trafficking (sale or rental of surfaces without documents to carry out mining activities) by these people. The case of illegal logging (forest harvesting without MAAE authorization), water pollution, and illegal hunting of wild animals has been going on for more than six years.

In the last 10 years, the increase in the price of gold at the international level has intensified the mining activity in the Ecuadorian Amazon territory, harming legal mining activities in the application, exploration, and exploitation phases [63]. Amazonian indigenous territories are the most affected with $85.8 \%$. Before granting mining rights, Ecuador's indigenous peoples have the right to negotiate with them, but the government recognizes that few indigenous people have rights to minerals on or under their lands. However, many indigenous peoples in the Amazon region do not want to exploit their lands [63,64]. This constitutes a major socioeconomic and environmental problem for communities near gold mining activities and, at the same time, a challenge to try to promote regulatory policies and respect for nature and Amazonian communities.

Ecuador's Mining Public Policy guarantees sector planning from 2019 to 2030. This seeks to achieve investment and increase production in the sector within a framework of environmental and social sustainability. It also seeks to improve the administration, regulation, auditing, and control of mining activities at the national level. Two of the most important axes seek sustainability and the fight against illegal mining [61]. In Article 93 of the Mining Law, $60 \%$ of royalties will be for productive projects and local development through municipal governments, parish councils, and, if the case merits, $50 \%$ of this percentage to the government of indigenous communities and/or territorial districts [56]. 
Table 5. Responsibilities of regulatory institutions in Ecuador.

Institution

Government/Constitution

Ministry of Energy and Non-Renewable Natural Resources

\section{Responsibilities}

Promote the development of artisanal mining, small-scale mining, medium-scale mining and large-scale mining, and promote their legalization so as to ensure technically adequate, socially just, and environmentally responsible conditions.

Responsible for the management of public policy on mining matters and the issuance of associated administrative agreements and resolutions, including the management of public policy for MAAPE.

National Strategic Plan for the Sustainable Development of Small and Artisanal Mining.

National Training and Education Plan in technical, economic, social and environmental areas.)

Technical assistance on production control, available reserves, ore quality, mining techniques, mining methods, ventilation, drainage, maintenance and industrial safety in the subsoil and on the surface, etc.

There is no special department in charge of the MAAPE.

Technical and administrative entity in charge of exercising the State's power to monitor, audit, intervene, and control the different phases of mining activity.

Establish a system for managing socio-environmental conflicts that may arise in the MAAPE sector, adopting clearly defined processes and procedures for their implementation.

Mining Regulation and Control Agency

Not having a special department to deal with ASGM.

Technically, economically, and financially independent from the Ministry.

Coordinate the technical assistance program.

Promote integrated management of sustainable mining development, mineral

processing, exploitation and maintenance of tailings, storage systems, closure of mining activities, and development of clean technologies.

Institutional, organizational, and technological strengthening of the institutions responsible for the management and control of the artisanal mining sector, small-scale mining, medium-scale mining, and large-scale mining.

Implement financing plans to promote and provide training in the artisanal, small-scale, medium-scale, and large-scale mining sectors.

Central Bank of Ecuador

Ministry of the Environment, Water, and Ecological Transition
Define, create, and control the implementation of the country's public environmental management system, including the artisanal, small-scale, medium-scale and large-scale mining sectors.

Table 6. Illegal ASLGM activities in the Amazon region of Ecuador.

\begin{tabular}{|c|c|c|}
\hline Title & Description & Year \\
\hline $\begin{array}{l}\text { Machinery used for illegal mining } \\
\text { activities seized in Sucumbios }\end{array}$ & $\begin{array}{l}\text { The Armed Forces, in support of the Ministry of Environment and } \\
\text { the Mining Regulation and Control Agency, carried out operations to } \\
\text { control illegal mining in the sector of Santa Rosa de Sucumbíos. }\end{array}$ & 2018 \\
\hline $\begin{array}{l}\text { Machinery used in illegal mining } \\
\text { activities seized }\end{array}$ & $\begin{array}{l}\text { The Armed Forces apprehended an Ecuadorian and a Colombian } \\
\text { involved in illegal mining activity in the sector of San Carlos, parish } \\
\text { Sevilla, canton Cascales. }\end{array}$ & 2021 \\
\hline $\begin{array}{l}\text { Indigenous communities continue to } \\
\text { denounce mining activities in Ecuador }\end{array}$ & $\begin{array}{l}\text { The Coordinadora de las Organizaciones Indígenas de la Cuenca } \\
\text { Amazónica (COICA) and the Confederación de Nacionalidades } \\
\text { Indígenas de la Amazonía Ecuatoriana (Confenaie) expressed their } \\
\text { concern and denounced the increasing mining activity in Ecuador. }\end{array}$ & 2018 \\
\hline
\end{tabular}


Table 6. Cont.

\begin{tabular}{|c|c|c|}
\hline Title & Description & Year \\
\hline $\begin{array}{l}\text { Operations against illegal mining were } \\
\text { carried out in Pastaza and Napo }\end{array}$ & $\begin{array}{c}\text { Operations against illegal mining in Pastaza and Napo. MAEA } \\
\text { officials with the support of soldiers from the Pastaza Jungle Brigade } \\
\text { carried out the controls. }\end{array}$ & 2016 \\
\hline Intense mining control in Alto Nangaritza & $\begin{array}{l}\text { The control of illegal mining in the province of Zamora Chinchipe } \\
\text { has resulted in the seizure of machinery, equipment, and fuels that } \\
\text { were used in the illegal activity. }\end{array}$ & 2018 \\
\hline $\begin{array}{l}\text { Illegal mining endangers Yantzaza's } \\
\text { drinking water catchment system }\end{array}$ & $\begin{array}{l}\text { The mayor of Yantzaza canton, Bladimir Armijos, indicated that his } \\
\text { drinking water source for more than } 12,000 \text { inhabitants is in danger } \\
\text { of contamination due to work carried out by illegal miners. }\end{array}$ & 2017 \\
\hline $\begin{array}{l}\text { Mining activity without permits in Alto } \\
\text { Nangaritza, Zamora Chinchipe }\end{array}$ & $\begin{array}{c}\text { The Nuevo Paraíso parish in the Alto Nangaritza area. The majority } \\
\text { of the population is Shuar and has no sources of employment. }\end{array}$ & 2018 \\
\hline $\begin{array}{l}\text { Alto Nangaritza, another virgin forest } \\
\text { under siege from mining in Ecuador }\end{array}$ & $\begin{array}{l}\text { Alto Nangaritza is one of the few remaining virgin native forests in } \\
\text { Ecuador and serves as a connection to Podocarpus National Park. }\end{array}$ & 2018 \\
\hline $\begin{array}{l}\text { Provincial and environmental authorities } \\
\text { harm villagers and favor miners }\end{array}$ & $\begin{array}{l}\text { The communities denounce that the MAAE and ARCOM favor } \\
\text { illegal miners, allowing free access, and violating the rights of the } \\
\text { commune and its inhabitants. This is in Orellana-Mushuc Hullacta } \\
\text { Commune, in the Punino sector. }\end{array}$ & 2021 \\
\hline
\end{tabular}

\subsubsection{Socio-Economic Impacts}

(a) Displacement of the Population and Loss of Livelihoods

In the late 1970s and early 1980s, the crisis in early mining companies and agriculture led to an expansion of small-scale gold mining. Although tinged by political, social, and environmental conflicts, in the last decade this sector has tended to consolidate itself as the most dynamic in the country in the extraction and processing of metallic minerals. In the early 1980s, two new mining districts emerged: Nambija in the Amazon region and Ponce Enriquez in the southwestern flanks of the Andes. Both were driven by the increase in international gold prices and by the agricultural crisis on the Ecuadorian coast, generated by the El Niño phenomenon. The group of people (associations with economic purposes) of informal miners had little technical-scientific knowledge in gold extraction. However, the cooperatives played a very important role in the process of legalizing concessions, which gave small-scale mining a greater margin of maneuver in its negotiations with the State and mining companies. The strengthening of small-scale mining took place in the 1990s through the consolidation of their productive processes, new forms of business-type organization, and their legalization. This was reaffirmed in interviews with the elderly residents of the nine cantons in the province of Zamora Chinchipe, who stated that in the early 1980s, with the crisis that was occurring at the local level, they migrated to these lands in the southern Amazon, tempted by rumors that these lands held large concentrations of gold.

The locals interviewed in connection with the Napo and Santiago rivers say that artisanal gold mining is considered traditional along the banks of these rivers and their tributaries. It is true that, by 1984, after the notable importance of gold production in the Nambija mines, in the Amazonian province of Zamora Chinchipe in southern Ecuador, expeditions and new human settlements expanded northward, more precisely in the center of the Amazon in the provinces of Morona Santiago, Pastaza, and Napo. Thus, one of the first records of gold production in 1988, according to official estimates provided by government authorities, was four metric tons of gold. However, these estimates corresponded to the declared part of the production, since a very important part was traded irregularly.

The results of the interviews indicate that there are currently two types of movements. The first is people who undertake expeditions that can last weeks or months to reach the metal mining deposits located mainly in the eastern and western foothills of the Andes and in the El Cóndor mountain range in the south-central Ecuadorian Amazon. In the northern zone, in the provinces of Sucumbíos, the cantons with the most mining activity are Cascales 
and Sucumbíos Alto. Gold mining expeditions take place in the mountains bordering Colombia and in protected areas such as the Cofan Bermejo Ecological Reserve. The main illegal and informal mining activities take place in the provinces of Zamora Chinchipe, Morona Santiago, Napo, and Sucumbíos.

During the tour of the gold mining areas (Table 1), it became evident that ASM gold mining activities have been accompanied by the formation of precarious settlements built by the miners, generally located in areas with irregular topography, distant from the basic services network, some of them temporary, and with a primarily male population (campstyle), which constitute areas with minimal sanitary conditions and high levels of natural risk. In the past, there have been serious disasters that have caused the death of dozens of people (Nambija) and have affected the surrounding river systems. Likewise, social conditions are characterized by an increase in social disorder, with a significant absence of social organization and public authorities. A similar phenomenon can be observed in ASGM mining, particularly on the banks of the main Amazonian rivers, where tourism development could be affected by mining if it is not framed within a context of sustainable development.

Historically, local communities in the Amazon have depended on agriculture and cattle ranching. On the other hand, tourism has taken on great importance in the last two decades with the emergence of community-based tourism and traditional lodges on the banks of Amazonian rivers. Seventy-three percent of the miners stated that they were previously involved in one of these activities, and $85 \%$ of the residents stated that some of their family members who are currently involved in mining were previously involved in agriculture, cattle ranching, or tourism. This change and loss of livelihoods has led to the abandonment of potential agricultural and livestock lands, which is reflected in improved production. These changes are produced by the temptation to obtain quick money and are produced by the daily pressures of carrying sustenance to cover family needs.

\section{(b) Migration of People, Economic Growth, and Cost of Living}

The communities consider that ASLGM does not contribute to the development of local communities; on the contrary, these activities bring with them health problems and conflicts among the population. Currently, local communities claim that the pandemic has increased artisanal mining activity throughout the Amazon region. This is due to the confinement, suspension of work, economic crisis, and lack of jobs. If we aim to solve the problems of ASLGM, solutions require challenges where collaboration and integrated work of gold mining stakeholders and local communities is paramount.

In relation to health, gold mining affects workers through high exposure to toxic substances such as $\mathrm{Hg}$ and cyanide. This occurs due to lack of hygiene and occupational safety, health, and environmental issues. Likewise, towns located in the lower basin of rivers with mining activity are affected by the high concentration of contaminants present in the water tributaries. These contaminants are found in the ichthyofauna that the communities take advantage of in all their fishing activities [50]. In addition, it was detected that mining increases the presence of mosquitoes and black flies, which act as vectors of viral diseases and generate illnesses in mine workers and families living near the gold mining shafts. Finally, veteran artisanal miners and inhabitants in nearby communities reported cognitive impairment. Clearly, long-term exposure to and ingestion of toxic substances from these mining activities may be the main cause.

In an interview with local authorities, indigenous peoples throughout the Amazon have announced their resistance to mining projects that allegedly threaten the future of the communities that inhabit this region. Indigenous leaders do not want mining companies or the government to consult on large-scale mining projects. In the interviews, they recalled that some of the mining projects were installed without consulting the local population, but rather that false processes of citizen participation were carried out (socialization of the project with local residents), as well as anomalies in the delivery of social compensation (food and tools for daily activities). The maximum representative stated that the indigenous 
struggle against mining projects in the country has caused more than 260 leaders to be persecuted by the State.

At the beginning of May, during a tour with the research team, new illegal artisanal mining activities became evident in places that a decade ago were indigenous territories or protected areas with little disturbance, specifically in Sucumbíos (Cáscales), Orellana (Alto Punino), and Napo (Chontapunta). Families near the mining activity, lacking economic income, are being affected by deforestation and water contamination. Locals say that prior to mining, activities such as fishing and bathing in the rivers were very common, but now for fear of contracting diseases they prefer not to use the services provided by the rivers. This has affected their livelihoods and regular day-to-day activities. As a result, the cost of living has increased; what they used to obtain from the ecosystem resources must now be purchased from neighboring towns, and for the vital resource of water, they now have to dig wells for fear of contracting diseases. Several residents interviewed said that the gold rush attracted people from the provincial capitals and canton capitals, as well as foreigners, Peruvians in the southern zone, and Colombians in the northern zone.

\section{(c) Water Scarcity and Health Effects}

At the social level throughout the Ecuadorian Amazon, indigenous peoples bear an enormous burden of health and livelihood impacts related to industrial development, including agriculture, mining, and extractive industries. Increased commitment to environmental control among indigenous peoples is needed to control contamination [48]. However, in studies 15 years ago, Hg levels in humans and fish near the Napo River communities were due to significant deforestation and volcanic soils. These had high levels of natural $\mathrm{Hg}$, since gold mining was almost non-existent at that time [50]. The presence of $\mathrm{Hg}$ suggests that deforestation and soil erosion (Hg leaching) contributed to $\mathrm{Hg}$ contamination of fish in the Napo River basin (Figure 2) [49].

In the field interviews, $67 \%$ of the residents of mining towns stated that one of their family members had presented a condition compatible with cancer. On the other hand, $87 \%$ of the local miners consider that in the last year they have presented health problems or illnesses compatible with headaches, hives, and red and white spots on the body, essentially on their extremities, and only $12 \%$ went for medical consultations at nearby health centers. Another major problem reported by the authorities of the Ministry of Environment and Local Governments is the fear of infiltration of contaminants into groundwater bodies. They indicate that further research is needed to know the status of the groundwater bodies, since most communities are considering using wells for water.

\section{(d) Environmental Impacts}

Historically, gold mining in the Ecuadorian Amazon has been the main source of $\mathrm{Hg}$ contamination [24,25]. Regarding this activity is the literature on $\mathrm{Hg}$ contamination in the northern part of the Amazonian region of Ecuador. However, legal and illegal mining has been present for years in the south of the country [41]. Anthropogenic activities increase metal concentrations in aquatic ecosystems [38]. The few studies in Sucumbíos and Orellana only evaluate impacts, in general, with respect to gold mining. In addition, studies on $\mathrm{Hg}$ contamination in Napo province are still incipient [25]. However, there is ample evidence of contamination by metals in legal mining areas of Tena, Puerto Napo, and Archidona $[28,38]$. The results indicate that the concentrations of these heavy metals have exceeded their permissible limits by 200 to $700 \%$. 


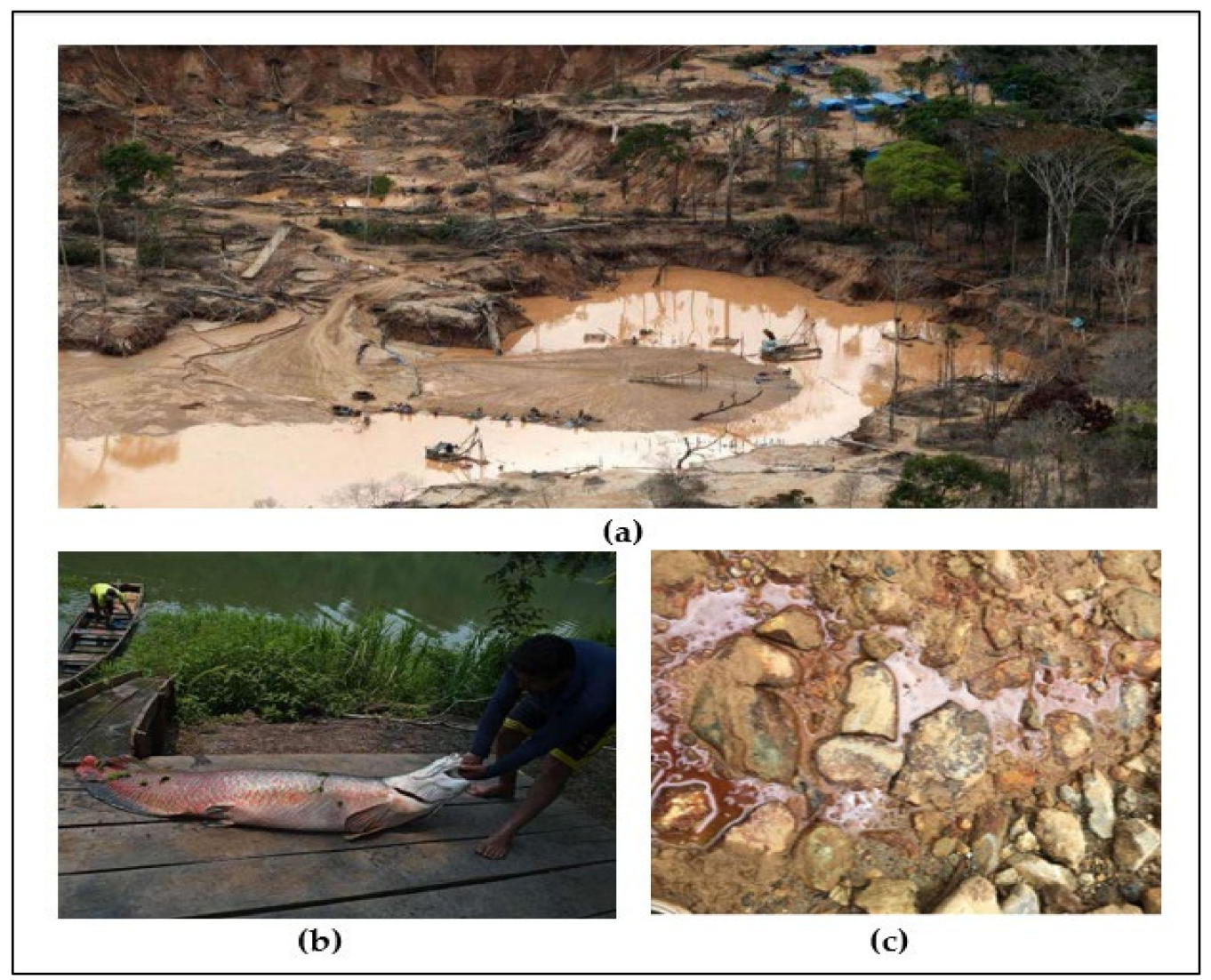

Figure 2. Environmental impacts in the Ecuadorian Amazon. (a) Deforestation in Amazonian villages due to gold mining, a problem of the last 40 years. (b) Contamination by leachate from mining areas. (c) Leaching of toxic contaminants due to lack of waste treatment from artisanal gold mining.

In the Northern and Southern Amazon (Napo River sub-basin, Aguarico River, and Santiago River), in terms of metallic elements, sedimentation, and presence of $\mathrm{Hg}$, it was determined that there are no differences in these three sub-basins. Elements such as $\mathrm{Co}$, $\mathrm{Ba}, \mathrm{Cd}$, and $\mathrm{Hg}$ are the result of oil activity and specifically mark spills. In the northern Amazon, there are high levels of $\mathrm{Hg}$ in the food chain. There is a potential risk when consuming fish due to As and $\mathrm{Hg}$ concentrations, since they exceed the limits established by the World Health Organization; the results indicate that the concentrations of these heavy metals have exceeded their permissible limits by 100 to $400 \%$. Intoxication is likely especially in children and pregnant and lactating women [45]. A study of several rivers in the Nangaritza river basin on exposure in school children residing near gold mining areas shows clear $\mathrm{Hg}$ contamination. Children living in high mountain areas have $\mathrm{Hg}$ concentrations outside the permissible limits. Thus, this activity causes environmental damage and a risk to human health $[39,40]$.

In some studies, such as $[13,28,39,40]$, evidence of high $\mathrm{Hg}$ contamination is shown in rivers of Zamora by gold mining [38], which exceeds the permissible limits, both for drinking water and for the proper development of wildlife. All of the miners interviewed affirmed that the use of mercury in gold extraction processes is still widespread. None of them stated that they use the currently recommended method such as cyanidation [57].

Recently, artisanal and illegal gold mining has increased in the northern Amazon region of Ecuador, specifically in Sucumbíos (Cáscales), Orellana (Alto Punino), and Napo (Chontapunta) (Figure 3). Families close to the mining activity, lacking economic income, are being affected by deforestation and water contamination with Hg. This disrupts their livelihoods and fishing activities with procedures that affect biodiversity, causing health impacts and water scarcity. The living costs of nearby communities are not affected. All this is due to the fact that there are agreements between the communities to keep the 
costs of goods and services at a balanced price for all. Economic activities in all the sites explored with gold mining activity benefit nearby communities in terms of security and road maintenance; communities without mining do not receive support for forest restoration or protection of protected areas, and agriculture is affected. The activities that benefit most Amazonian communities are agriculture, cattle ranching, and fishing. In general, people mentioned fishing and agriculture (palm, banana, cassava, cacao, and coffee) as their main livelihood activities and cattle ranching as a secondary source of food and income. Households near artisanal mining activities attribute it as their main source of income, while most remote indigenous communities perceive it as harmful to their rivers and aquatic life. This has had a significant impact on the lives of Amazonian communities.

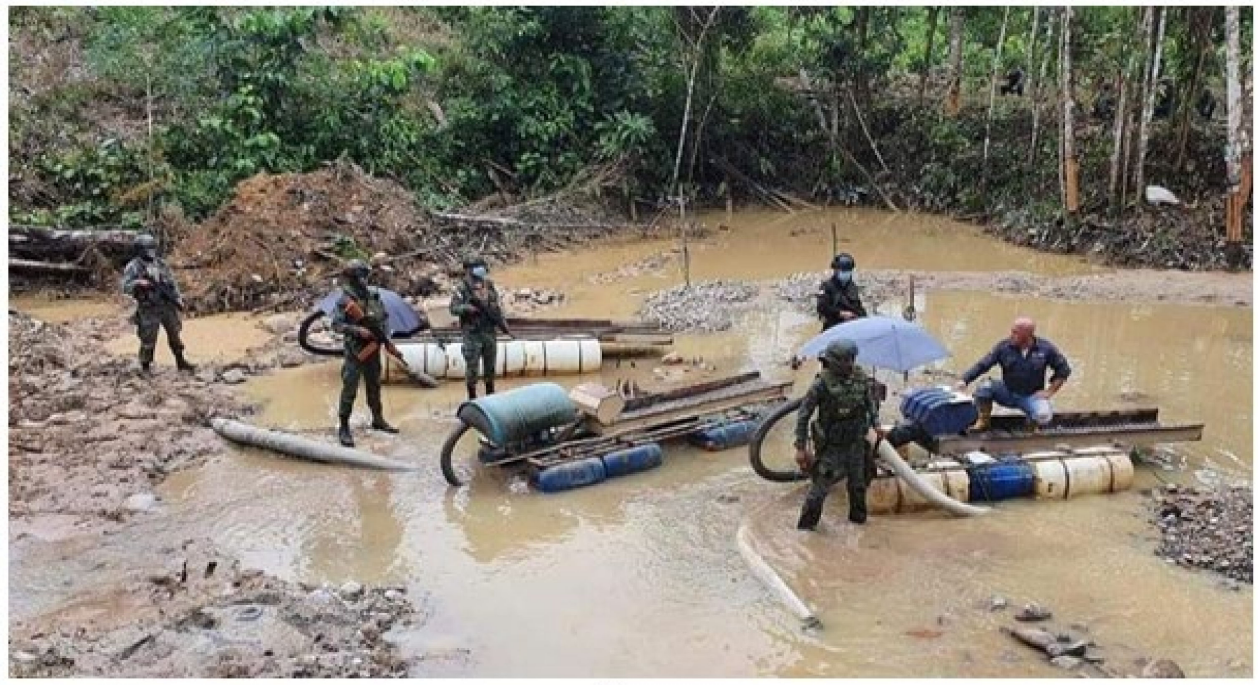

(a)

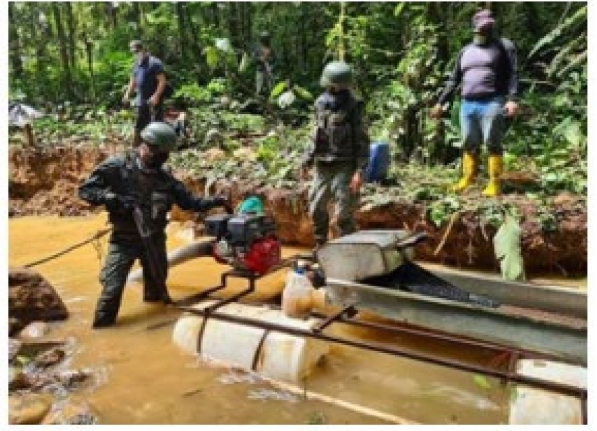

(b)

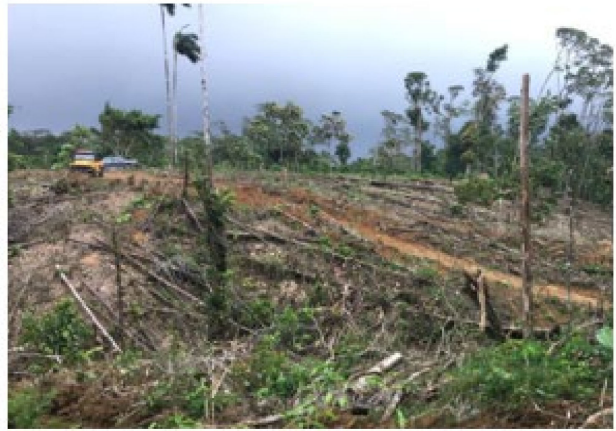

(c)

Figure 3. Illegal mining in the northern Amazon region of Ecuador. (a) Armed forces operations against artisanal gold mining in Sucumbíos (Cáscales). (b) Operation and closure of illegal mining in Orellana (Alto Punino). (c) Impacts of illegal gold mining in Napo (Chontapunta).

The harmful effects of $\mathrm{Hg}$ in the southern sector of the Amazon as a result of gold mining have intensified since the 1980s, when artisanal gold mining began to develop [13]. Although in this region ASLGM generates important economic values, it also causes various types of contamination [41]. Zamora Chinchipe is the largest generator of gold mining economy. Most of the gold extraction originates from artisanal and small-scale mining $[13,41]$. The geology of the site, which is rich in polysulfide and metamorphic rocks, may be the reason for the presence of $\mathrm{Hg}$. However, $\mathrm{Hg}$ concentrations in the soils of the Yacuambi River exceed normal concentrations. This is due to the constant use of $\mathrm{Hg}$ as amalgam in gold mining processes [41]. The environmental changes caused by artisanal gold mining in the Nambija district because of $\mathrm{Hg}$ register high contamination by this metal, while soil erosion increases $\mathrm{Hg}$ concentrations of sediments in the different aquatic 
ecosystems of the Nambija stream and river [13,39]. This not only represents a serious risk to the health of the organisms and plants that live in the water, but also represents a threat to the people who use the ecosystem services of the water bodies.

Interviews and field observations identified that environmental impacts on soils and water resources are caused by the recurrent inadequate discharge of sediments from gold mining. In addition, mining activity affects water resources, natural landscapes, and fauna, being the aspects that have suffered the greatest impact [65]. These forms of contamination are: (1) infiltration of contaminants into the soil from mining extraction; (2) illegal dumping of toxic substances ( $\mathrm{Hg}$ ) into bodies of water; (3) infiltration of toxic substances from mine tailings; (4) infiltration of toxic substances into the soil from mining tailings; (5) soil erosion from mining activities; (6) soil erosion from mining tailings; (7) soil erosion due to land-use changes.

Parish authorities, miners, and residents say that gold mining activity has been gradually damaging environmental problems. This is related to drastic changes in the landscape (land use modification, soil erosion, relief modification, river patterns, deforestation). The biotic and abiotic components are more affected as a consequence of using rudimentary techniques in the extraction processes and the use of $\mathrm{Hg}$ as the main element in gold mining processes [66]. Mining activities also affect the flora, fauna, and microbiota present in soils and water bodies. This is due to the inability to adapt to toxic environments in mining areas.

\subsubsection{Challenges of Gold Mining in the Ecuadorian Amazon Zone}

ASLGM represents a great economic contribution to the country; however, it harms the health of the communities and generates environmental problems [50,64]. After analyzing the history and current situation in the Ecuadorian Amazon, the environmental and social damages were shown to be greater than the economic benefits; however, this activity has increased internationally due to the increase in the price of gold, with greater legal and illegal mining activity in the COVID-19 pandemic. The authorities responsible for mining control should focus their efforts on enforcing mining regulations in a scenario that reduces environmental and socioeconomic impacts and is beneficial to communities near mining. The pandemic has modified the growth of illegal mining, and although the activities are not properly controlled and sanctioned, it is possible to analyze and propose essential measures that will improve artisanal and industrial mining activity in the future. In the case of artisanal mining, communities are being affected by amalgams ( $\mathrm{Hg})$, i.e., affecting their health and livelihoods (tailings and river contamination, $\mathrm{Hg}$ contamination of aquatic biodiversity), where indigenous peoples are the most dissatisfied. In addition, the IWMAs affect the amount of natural vegetation and runoff rates. While Ecuador is theoretically more environmentally conscious than other countries, its political, economic, and functional challenges limit the country from effectively implementing these measures in practice.

Due to a lack of understanding of the impact of the ASLGM, lack of clarity in the policy framework, and limited resources, Ecuador's controls and compliance have failed. This allows for rethinking new alternatives to reduce environmental and socioeconomic impacts. When the usual methods of pollution and hazard control are difficult to implement, knowledge is a viable strategy [67]. It is a new opportunity that, by rebuilding it, the sector will be better, more sustainable and inclusive, and the benefits of gold mining will be shared more widely and fairly. It is important that the authorities in Ecuador's Amazon region are interested in strengthening dialogue and cooperation with communities.

Environmental and socio-economic problems, such as deforestation, river contamination, health, loss of livelihoods among others, coupled with a history of $\mathrm{Hg}$ impacts and the current situation in the Amazonian area of Ecuador, is perhaps one of the biggest challenges for the sector and governments. To address this challenge, the strategies based on this study on the history, current situation, and expert judgment could be used in combination with existing regulations to strengthen fundamental aspects (Table 7). If communities 
near gold mining are aware of the unavoidable risks, they are more likely to advocate for improvements in legislation, regulation, toxic waste management, and remediation.

Table 7. Suggested measures to improve the ASLGM in the Ecuadorian Amazon.

(a) Improve enforcement of existing regulations by strengthening the central authority responsible for oversight of mining activities.

(b) Promote local government and public participation in environmental management.

(c) Facilitate the reorganization of small companies into large companies that are strong enough to maintain reasonable environmental and exploration obligations.

Authorities should focus efforts on creating new policies to take advantage of the potential of mineral resources in the Amazon region between Ecuador in a sustainable and balanced manner. The legal classification of gold mining in Ecuador allows for the possibility of an organization of miners. This could facilitate efficient communication between mining representatives, miners, regulators, and the community to promote greater awareness of the impacts of ASLGM. However, increasing gold prices and impacts are leading to changes in policies and the way mining activities work. Artisanal and industrial gold miners around the world are increasingly trying to improve and easily apply new technologies and techniques that regulate excessive pollution to the environment [68]. Therefore, training the mining sector to use more efficient technologies will likely result in more efficient plants, less pollution, reduced socio-economic impacts, and the comfort of communities that depend on agricultural and fishing activities for their livelihoods and economy.

\section{Discussion}

In this study, the literature review and field work have shown evidence of possible future implications on environmental and socio-economic impacts as a result of gold mining activities [20,69]. The Peruvian, Colombian, Ecuadorian, and Brazilian Amazon share similar impacts from $\mathrm{Hg}$ emissions in ASLGM activities. The extraction processes and the large extension of detected gold mining areas generate contaminants such as $\mathrm{Hg}$ for fresh water, concern for its environmental impacts, and socioeconomic problems in local communities in the Ecuadorian Amazon [70-72]. Studies show that the Ecuadorian Amazon is more prone to serious irreversible damage to the environment, which has serious effects on aquatic ecosystems and biodiversity. New mining technologies and techniques should be the priority to reduce these impacts in the Ecuadorian Amazon region.

The recent impacts of ASLGM and the large extension of gold mining areas are damaging Amazonian ecosystems [71] and are of concern to local communities [72]. It is necessary to know the expansion of ASLGM over time to take measures that benefit stakeholders. On the other hand, ASLGM must improve the coexistence, agreements of the communities close to this activity, as a key policy to change in the future. This will allow ASLGM to prosper at the level of environmental, economic, and social care, linked to the development of the country. It is necessary to expand knowledge about gold mining in terms of the impacts caused by this activity in order to improve political and environmental management.

The results show the lack of control and enforcement of the law against illegal artisanal gold mining activities, and this highlights the little evidence that exists in the literature on good practices of the law or affected by corruption. If mining activity is illegal, local authorities should enforce the law and close the mines. However, illegal gold mining activity still persists. Action should be taken to avoid river pollution and health risks when consuming fish [73]. It is important to take advantage of information to help communities being affected by illegal activities. In addition, future decisions should be made on the effectiveness and proper enforcement of the law to reduce illegal environmental activities 
and address issues of voluntary compliance with stricter regulations or policies. Finally, it is important to highlight that the conditions and perception of artisanal, small-scale, and industrial mining by communities in the area of influence is similar to what is reflected in studies carried out in other countries such as Brazil [33], Colombia [74,75], Peru [32], Ghana [31], and Zambia [76], where it has caused are health problems, conflicts, and environmental impacts.

\section{Conclusions}

The results show that mining activity in the Ecuadorian Amazon region has increased over the last four decades. At first, it was an artisanal and subsistence mining activity, which was complementary to other activities, but between 1980 and 2000, a greater number of family groups came to this region tempted by the stories of the large quantities of gold available. Since then, illegal ASGM activities have increased, with a higher percentage in the south (Zamora Chinchipe and Morona Santiago) and north (Sucumbíos and Napo). On the other hand, it is important to note that during the government of Rafael Correa (2007-2017), that is, in the last decade, large-scale mining was normalized and strengthened. Thus, at present, the total number of legalized concessions in all its forms amounts to 1462 in the Amazon region. Faced with this increase in ASGM and large-scale gold mining activity, the government has promoted the creation of new institutions, policies, and laws with the objective of controlling mining activity and reducing socio-environmental impacts. However, when it comes to evaluating and in reality, it is evident that the number of provincial and local government personnel for the control and monitoring of these activities, including managers and technicians, does not exceed 10 people per province in the Amazon region. In other words, there is evidence of a serious problem: the state is incapable of properly controlling and monitoring ASGM and large-scale mining activities. From the community and sectoral leaders' perspective, they believe that the state is not capable of ensuring the conservation and good living of the people linked to mining activities.

Historically, socio-environmental problems due to ASGM and large-scale gold mining activities have been increasing, and this is reflected in the evidence of heavy metal contamination of water bodies, atmosphere and soil. Additionally, from the perspective of $100 \%$ of the stakeholders interviewed, they are aware of the impact on the natural environment, and they do not have evidence or documentation, but the changes in the physical conditions of water due to erosion on riverbanks and deforestation have affected their livelihoods and cost of living, as well as a shortage of water affecting their daily lives.

Given the socio-environmental problems in gold mining due to the indiscriminate use of $\mathrm{Hg}$, an element that is prohibited in the country, it is necessary to establish measures to help reduce the environmental and social impact of this activity. One of the measures that should be applied by the state and its institutions is education and counseling on ASM gold mining, focusing on the implications for health and possible diseases. In addition, there should be socializing that teaches that the use of other processes and technologies would allow for a greater use of gold compared to $\mathrm{Hg}$. With respect to large-scale gold mining, it is considered necessary to strengthen the control institutions and carry out proper follow-up control in order to enforce compliance with their environmental management plans.

The results of this research provide interesting data from the perspective of the stakeholders in the gold mining activity in the Ecuadorian Amazon, for managers and as a basis for further research. The main limitations in the research process were the difficulty to mobilize and enter the communities due to the pandemic situation of COVID-19 and the conflictive nature of having contact with miners and local residents to access interviews. Finally, further research is encouraged to evaluate the concentration of heavy metals in surface and subway water bodies, as well as an analysis of the conflicts caused by ASM and large-scale mining. 


\begin{abstract}
Author Contributions: Conceptualization, C.M.-R. and S.S.; methodology, C.M.-R., J.C.-C., S.S. and G.D.; software, C.M.-R. and J.C.-C.; formal analysis, C.M.-R., J.C.-C., S.S., J.F.-T., S.S.-C., A.B.-B. and G.D.; investigation, C.M.-R., J.C.-C., J.F.-T., S.S.-C., A.B.-B. and G.D.; writing-original draft preparation, C.M.-R. and J.C.-C.; writing-review and editing, C.M.-R., S.S., and G.D.; supervision, S.S., and G.D; project administration, C.M.-R., S.S. and G.D.; resources, C.M.-R. and S.S. All authors have read and agreed to the published version of the manuscript.
\end{abstract}

Funding: This research received the financial support of the European Commission through the projects: H2020-MSCA-RISE REMIND “Renewable Energies for Water Treatment and Reuse in Mining Industries" (Grant agreement ID: 823948).

Acknowledgments: The authors are grateful for the financial support field work of GREEN AMAZON ECUADOR, and Escuela Superior Politécnica de Chimborazo (ESPOCH). As lead author, C.M.R., I thank the Doctoral School of the University of Calabria for allowing me to pursue a doctorate.

Conflicts of Interest: The authors declare no conflict of interest.

\title{
References
}

1. Walser, G. Economic Impact of World Mining. 2002. Available online: https://inis.iaea.org/collection/NCLCollectionStore/ _Public/33/032/33032900.pdf (accessed on 27 October 2021).

2. Dubiński, J. Sustainable development of mining mineral resources. J. Sustain. Min. 2013, 12, 1-6. [CrossRef]

3. Tost, M.; Bayer, B.; Hitch, M.; Lutter, S.; Moser, P.; Feiel, S. Metal mining's environmental pressures: A review and updated estimates on CO2 emissions, water use, and land requirements. Sustainability 2018, 10, 2881. [CrossRef]

4. Boldy, R.; Santini, T.; Annandale, M.; Erskine, P.D.; Sonter, L.J. Understanding the impacts of mining on ecosystem services through a systematic review. Extr. Ind. Soc. 2021, 8, 457-466. [CrossRef]

5. Spiegel, S.J.; Agrawal, S.; Mikha, D.; Vitamerry, K.; Le Billon, P.; Veiga, M.; Konolius, K.; Paul, B. Phasing Out Mercury? Ecological Economics and Indonesia's Small-Scale Gold Mining Sector. Ecol. Econ. 2017, 144, 1-11. [CrossRef]

6. Orimoloye, I.R.; Mazinyo, S.P.; Kalumba, A.M.; Nel, W.; Adigun, A.I.; Ololade, O.O. Wetland shift monitoring using remote sensing and GIS techniques: Landscape dynamics and its implications on Isimangaliso Wetland Park, South Africa. Earth Sci. Inform. 2019, 12, 553-563. [CrossRef]

7. Orimoloye, I.R.; Kalumba, A.M.; Mazinyo, S.P.; Nel, W. Geospatial analysis of wetland dynamics: Wetland depletion and biodiversity conservation of Isimangaliso Wetland, South Africa. J. King Saud Univ.-Sci. 2018, 32, 90-96. [CrossRef]

8. Luo, W.; Lu, Y.; Zhang, Y.; Fu, W.; Wang, B.; Jiao, W.; Wang, G.; Tong, X.; Giesy, J.P. Watershed-scale assessment of arsenic and metal contamination in the surface soils surrounding Miyun Reservoir, Beijing, China. J. Environ. Manag. 2010, 91, $2599-2607$. [CrossRef]

9. Bozigar, M.; Gray, C.L.; Bilsborrow, R.E. Oil Extraction and Indigenous Livelihoods in the Northern Ecuadorian Amazon. World Dev. 2016, 78, 125-135. [CrossRef] [PubMed]

10. Saldarriaga-Isaza, A.; Villegas-Palacio, C.; Arango, S. Phasing out mercury through collective action in artisanal gold mining: Evidence from a framed field experiment. Ecol. Econ. 2015, 120, 406-415. [CrossRef]

11. Bank, M.S.; Vignati, D.A.L.; Vigon, B. United Nations Environment Programme's Global Mercury Partnership: Science for successful implementation of the Minamata Convention. Environ. Toxicol. Chem. 2014, 33, 1199-1201. [CrossRef]

12. Protschky, S.; Morgan, R.A. Historicising sulfur mining, lime extraction and geotourism in Indonesia and Australia. Extr. Ind. Soc. 2021, 8, 100881. [CrossRef]

13. Ramírez Requelme, M.E.; Ramos, J.F.F.; Angélica, R.S.; Brabo, E.S. Assessment of Hg-contamination in soils and stream sediments in the mineral district of Nambija, Ecuadorian Amazon (example of an impacted area affected by artisanal gold mining). Appl. Geochem. 2003, 18, 371-381. [CrossRef]

14. Navarro Cardenas, M. Investigación histórica de la minería en el Ecuador: Quito. Dir. Comun. Soc. Minist. Energía Minas 1986, 1, 185.

15. Carlos, M.-R.; Straface, S.; D'Orio, G. Gold mining in Ecuador: Innovative recommendations for the management and remediation of mercury-contaminated waters. Green World J. 2021, 4, 11.

16. Rivera-Parra, J.L.; Beate, B.; Diaz, X.; Ochoa, M.B. Artisanal and Small Gold Mining and Petroleum Production as Potential Sources of Heavy Metal Contamination in Ecuador: A Call to Action. Int. J. Environ. Res. Public Health 2021, 18, 2794. [CrossRef] [PubMed]

17. Adler Miserendino, R.; Bergquist, B.A.; Adler, S.E.; Guimarães, J.R.D.; Lees, P.S.J.; Niquen, W.; Velasquez-López, P.C.; Veiga, M.M. Challenges to measuring, monitoring, and addressing the cumulative impacts of artisanal and small-scale gold mining in Ecuador. Resour. Policy 2013, 38, 713-722. [CrossRef]

18. Veiga, M.M. Introducing New Technologies for Abatement of Global Mercury Pollution in Latin America; CETEM/CNPq: Rio de Janeiro, Brazil, 1997; ISBN 8572271007.

19. Bridge, G. Contested terrain: Mining and the environment. Annu. Rev. Environ. Resour. 2004, 29, 205-259. [CrossRef] 
20. Obiri, S.; Mattah, P.A.D.; Mattah, M.M.; Armah, F.A.; Osae, S.; Adu-Kumi, S.; Yeboah, P.O. Assessing the environmental and socio-economic impacts of artisanal gold mining on the livelihoods of communities in the Tarkwa Nsuaem municipality in Ghana. Int. J. Environ. Res. Public Health 2016, 13, 160. [CrossRef]

21. Veiga, M.M.; Gunson, A.J. Gravity concentration in artisanal gold mining. Minerals 2020, 10, 1026. [CrossRef]

22. Mestanza-Ramón, C.; Paz-Mena, S.; López-Paredes, C.; Jimenez-Gutierrez, M.; Herrera-Morales, G.; D’Orio, G.; Straface, S. History, Current Situation and Challenges of Gold Mining in Ecuador's Litoral Region. Land 2021, 10, 1220. [CrossRef]

23. Mestanza-Ramón, C.; Ordoñez-Alcivar, R.; Arguello-Guadalupe, C.; Carrera-Silva, K.; D'Orio, G.; Straface, S. History, Socioeconomic Problems and Environmental Impacts of Gold Mining in the Andean Region of Ecuador. Int. J. Environ. Res. Public Health 2022, 19, 1190. [CrossRef]

24. Lessmann, J.; Fajardo, J.; Muñoz, J.; Bonaccorso, E. Large expansion of oil industry in the Ecuadorian Amazon: Biodiversity vulnerability and conservation alternatives. Ecol. Evol. 2016, 6, 4997-5012. [CrossRef]

25. Naranjo, C.G.P.; Maurice, L.; de Lourdes Ochoa-Herrera, V.; López, F.; Egas, D.A.; Lagane, C.; Besson, P. Determinación de elementos mayores en sedimentos provenientes de zonas afectadas por actividades petroleras en Ecuador. ACI Av. Cienc. Ing. 2015, 7. [CrossRef]

26. Zarroca, M.; Linares, R.; Velásquez-López, P.C.; Roqué, C.; Rodríguez, R. Application of electrical resistivity imaging (ERI) to a tailings dam project for artisanal and small-scale gold mining in Zaruma-Portovelo, Ecuador. J. Appl. Geophys. 2015, 113, 103-113. [CrossRef]

27. Velásquez-López, P.C.; Veiga, M.M.; Hall, K. Mercury balance in amalgamation in artisanal and small-scale gold mining: Identifying strategies for reducing environmental pollution in Portovelo-Zaruma, Ecuador. J. Clean. Prod. 2010, 18, $226-232$. [CrossRef]

28. Mora, A.; Jumbo-Flores, D.; González-Merizalde, M.; Bermeo-Flores, S.A.; Alvarez-Figueroa, P.; Mahlknecht, J.; HernándezAntonio, A. Heavy Metal Enrichment Factors in Fluvial Sediments of an Amazonian Basin Impacted by Gold Mining. Bull. Environ. Contam. Toxicol. 2019, 102, 210-217. [CrossRef]

29. Sánchez-Vázquez, L.; Espinosa-Quezada, M.G.; Eguiguren-Riofrío, M.B. "Golden reality" or the "reality of gold": Artisanal mining and socio-environmental conflict in Chinapintza, Ecuador. Extr. Ind. Soc. 2016, 3, 124-128. [CrossRef]

30. Chiaradia, M.; Vallance, J.; Fontboté, L.; Stein, H.; Schaltegger, U.; Coder, J.; Richards, J.; Villeneuve, M.; Gendall, I. U-Pb, Re-Os, and 40Ar/39Ar geochronology of the Nambija Au-skarn and Pangui porphyry Cu deposits, Ecuador: Implications for the Jurassic metallogenic belt of the Northern Andes. Miner. Depos. 2008, 44, 371-387. [CrossRef]

31. Long, R.N.; Renne, E.P.; Basu, N. Understanding the Social Context of the ASGM Sector in Ghana: A Qualitative Description of the Demographic, Health, and Nutritional Characteristics of a Small-Scale Gold Mining Community in Ghana. Int. J. Environ. Res. Public Health 2015, 12, 12679-12696. [CrossRef] [PubMed]

32. Wyatt, L.; Permar, S.R.; Ortiz, E.; Berky, A.; Woods, C.W.; Amouou, G.F.; Itell, H.; Hsu-Kim, H.; Pan, W. Mercury Exposure and Poor Nutritional Status Reduce Response to Six Expanded Program on Immunization Vaccines in Children: An Observational Cohort Study of Communities Affected by Gold Mining in the Peruvian Amazon. Int. J. Environ. Res. Public Health 2019, 16, 638. [CrossRef] [PubMed]

33. Ueno, T.M.; Lima, L.N.; Sardinha, D.M.; Rodrigues, Y.C.; Souza, H.U.; Teixeira, P.R.; Guimarães, R.J.; Lima, K.V.; Ventura, A.M. Socio-Epidemiological Features and Spatial Distribution of Malaria in an Area under Mining Activity in the Brazilian Amazon Region. Int. J. Environ. Res. Public Health 2021, 18, 10384. [CrossRef]

34. Villacís, B.; Carrillo, D. País Atrevido: La Nueva Cara Sociodemográfica del Ecuador, 1st ed.; Instituto Nacional de Estadística y Censos (INEC): Quito, Ecuador, 2012.

35. Instituto Oceanográfico de la Armada del Ecuador-INOCAR. Derrotero de la Costa Continental e Insular del Ecuador; INOCAR: Guayaquil, Ecuador, 2005; Volume 4.

36. Agencia de Regulación y Control Minero. Geoportal de Catastro Minero: Límites Territoriales Internos, CONALI 2020. Available online: https://gis-sigde.maps.arcgis.com/apps/webappviewer/index.html?id=8b53f9388c034b5e8e3147f03583d7ec (accessed on 18 July 2021).

37. Agencia de Regulación y Control Minero. Regulaciones. Available online: https://www.gob.ec/regulaciones (accessed on 25 September 2021).

38. Capparelli, M.V.; Moulatlet, G.M.; de Souza Abessa, D.M.; Lucas-Solis, O.; Rosero, B.; Galarza, E.; Tuba, D.; Carpintero, N.; Ochoa-Herrera, V.; Cipriani-Avila, I. An integrative approach to identify the impacts of multiple metal contamination sources on the Eastern Andean foothills of the Ecuadorian Amazonia. Sci. Total Environ. 2020, 709, 136088. [CrossRef] [PubMed]

39. Abrahan, M.; Diana, J.F.; Jürgen, M. Levels of MN, ZN, PB and HG in sediments of the zamora river, Ecuador. Rev. Int. Contam. Ambient. 2018, 34, 245-249.

40. González-Merizalde, M.V.; Menezes-Filho, J.A.; Cruz-Erazo, C.T.; Bermeo-Flores, S.A.; Sánchez-Castillo, M.O.; Hernández-Bonilla D.; Mora, A. Manganese and Mercury Levels in Water, Sediments, and Children Living Near Gold-Mining Areas of the Nangaritza River Basin, Ecuadorian Amazon. Arch. Environ. Contam. Toxicol. 2016, 71, 171-182. [CrossRef] [PubMed]

41. López-Blanco, C.; Collahuazo, L.; Torres, S.; Chinchay, L.; Ayala, D.; Benítez, P. Mercury Pollution in Soils from the Yacuambi River (Ecuadorian Amazon) as a Result of Gold Placer Mining. Bull. Environ. Contam. Toxicol. 2015, 95, 311-316. [CrossRef] [PubMed] 
42. Tarras-Wahlberg, N.; Flachier, A.; Lane, S.N.; Sangfors, O. Environmental impacts and metal exposure of aquatic ecosystems in rivers contaminated by small scale gold mining: The Puyango River basin, southern Ecuador. Sci. Total Environ. 2001, 278, 239-261. [CrossRef]

43. Tarras-Wahlber, N.H.; Flachier, A.; Fredriksson, G.; Lane, S.; Lundberg, B.; Sangfors, O. Environmental impact of small-scale and artisanal gold mining in southern Ecuador. AMBIO J. Hum. Environ. 2000, 29, 484-491. [CrossRef]

44. Osorio Rivera, M.; Mejía Reinoso, T.; Flores Orozco, Á.; Villa Uvidia, D.; Toledo Castillo, N.; Vaca Zambrano, S.; Suárez Ávila, L.; Peñafiel Moncayo, I.; Salazar Huaraca, S.; Espinoza Sandoval, J.; et al. Evolución Cronológica Del Proceso De Explotación De Oro En El Mundo Y En Ecuador Y Sus Efectos Sobre El Ambiente. Perfiles 2018, 2, 56-68. [CrossRef]

45. Moreno Vallejo, C.A. Impactos de la Actividad Petrolera en la Amazonía Ecuatoriana. Ph.D. Thesis, Universidad San Francisco de Quito (USFQ), Quito, Ecuador, 2017.

46. Almeida, M.D. Estudio de Caso Sobre la Gobernanza del Sector Minero en el Ecuador. 2019. Available online: https://www. cepal.org/es/publicaciones/44876-estudio-caso-la-gobernanza-sector-minero-ecuador (accessed on 12 July 2021).

47. Carrión, A. Procesos. Revista Ecuatoriana de Historia; Publisheer: City, Country, 2017; p. 95.

48. Fernández-Llamazares, Á.; Garteizgogeascoa, M.; Basu, N.; Brondizio, E.S.; Cabeza, M.; Martínez-Alier, J.; McElwee, P.; ReyesGarcía, V. A State-of-the-Art Review of Indigenous Peoples and Environmental Pollution. Integr. Environ. Assess. Manag. 2020, 16, 324-341. [CrossRef]

49. Mainville, N.; Webb, J.; Lucotte, M.; Davidson, R.; Betancourt, O.; Cueva, E.; Mergler, D. Decrease of soil fertility and release of mercury following deforestation in the Andean Amazon, Napo River Valley, Ecuador. Sci. Total Environ. 2006, 368, 88-98. [CrossRef]

50. Webb, J.; Mainville, N.; Mergler, D.; Lucotte, M.; Betancourt, O.; Davidson, R.; Cueva, E.; Quizhpe, E. Mercury in Fish-eating Communities of the Andean Amazon, Napo River Valley, Ecuador. Ecohealth 2004, 1, SU59-SU71. [CrossRef]

51. Roy, B.A.; Zorrilla, M.; Endara, L.; Thomas, D.C.; Vandegrift, R.; Rubenstein, J.M.; Policha, T.; Ríos-Touma, B.; Read, M. New Mining Concessions Could Severely Decrease Biodiversity and Ecosystem Services in Ecuador: Trop. Conserv. Sci. $2018,11$. [CrossRef]

52. Quezada, C. Análisis de las Reformas Introducidas a la Ley de Minería del Ecuador: Estudio del Proyecto Llano Grande. Ph.D. Thesis, Universidad de Cuenca, Cuenca, Ecuador, 2016.

53. Davidov, V. Mining versus Oil Extraction: Divergent and Differentiated Environmental Subjectivities in "Post-Neoliberal" Ecuador. J. Lat. Am. Caribb. Anthropol. 2013, 18, 485-504. [CrossRef]

54. Asamblea Nacional: Comisión lejislativa y de Fiscalización. Ley de Mineria del República del Ecuador; Publisher: Quito, Ecuador, 2018; p. 65.

55. Asamblea Constitucional del Ecuador. Constitucion de la Republica del Ecuador; Publisher: City, Country, 2008 ; pp. 1-222.

56. Ministerio de Turismo del Ecuador. Reglamento General a la Ley de Minería; Publisher: City, Country, $2015 ;$ p. 11.

57. Schudel, G.; Kaplan, R.; Adler Miserendino, R.; Veiga, M.M.; Velasquez-López, P.C.; Guimarães, J.R.D.; Bergquist, B.A. Mercury isotopic signatures of tailings from artisanal and small-scale gold mining (ASGM) in southwestern Ecuador. Sci. Total Environ. 2019, 686, 301-310. [CrossRef] [PubMed]

58. Ministerio de Minas y Energía (MinMinas). Plan Estratégico Sectorial Para la Eliminación del Uso del Mercurio. La Ruta Hacia un Beneficio Sostenible del Oro; Publisher: Bogota, Colombia, 2016.

59. Ley de Mineria; Corporacion de Estudios y Publicaciones: Quito, Ecuador, 2017; p. 1088.

60. Spiegel, S. Analysis of Formalization Approaches in the Artisanal and Small-Scale Gold Mining Sector Based on Experiences in Ecuador, Mongolia, Peru, Tanzania and Uganda: Tanzania Case Study; United Nations Environment Programme: Nairobi, Kenya, 2012; Volume 18

61. Red Amazónica de Información Socioambiental Georreferenciada (RAISG) Minería Ilegal. Available online: https://mineria. amazoniasocioambiental.org/ (accessed on 21 November 2021).

62. Veit, P.; Quijano Vallejos, P. COVID-19, Rising Gold Prices and Illegal Mining Threaten Indigenous Lands in the Amazon; World Resources Institute: Washington, DC, USA.

63. Red Amazónica de Información Socioambiental Georreferenciada (RAISG) Minería, Noticias. Available online: https://mineria. amazoniasocioambiental.org/pesquisas/ (accessed on 10 September 2021).

64. Vallejos, P.Q.; Veit, P. Mining Threatens 20\% of Indigenous Lands in the Amazon; Publisher: City, Country, 2020.

65. Orellana, L.; Méndez, P.; Mishquero, D. Conflictos e impactos generados por minería: Una amenaza al territorio de la comunidad indígena Cofán de Sinangoe, Sucumbíos-Ecuador. Green World J. 2019, 3, 3. [CrossRef]

66. Mora-Silva, D.; Coronel-Espinoza, B. Minería Aurífera Artesanal en la Amazonía norte del Ecuador: Gestión e impactos socio-ambientales en la Parroquia El Dorado de Cascales, Provincia de Sucumbíos. Green World J. 2021, 4, 3. [CrossRef]

67. Tietenberg, T.; Wheeler, D. Empowering the community: Information strategies for pollution control. In Frontiers of Environmental Economics; Edward Elgar: Cheltenham, UK, 2001; pp. 85-120.

68. Hinton, J.J.; Veiga, M.M.; Veiga, A.T.C. Clean artisanal gold mining: A utopian approach? J. Clean. Prod. 2003, 11, 99-115. [CrossRef]

69. Klubi, E.; Abril, J.M.; Nyarko, E.; Delgado, A. Impact of gold-mining activity on trace elements enrichment in the West African estuaries: The case of Pra and Ankobra rivers with the Volta estuary (Ghana) as the reference. J. Geochem. Explor. 2018, 190, 229-244. [CrossRef] 
70. Rozo, S.V. Unintended effects of illegal economic activities: Illegal gold mining and malaria. World Dev. 2020, 136, 105119. [CrossRef]

71. Kahhat, R.; Parodi, E.; Larrea-Gallegos, G.; Mesta, C.; Vázquez-Rowe, I. Environmental impacts of the life cycle of alluvial gold mining in the Peruvian Amazon rainforest. Sci. Total Environ. 2019, 662, 940-951. [CrossRef]

72. Lobo, F.D.L.; Souza-Filho, P.W.M.; Novo, E.M.L.d.M.; Carlos, F.M.; Barbosa, C.C.F. Mapping mining areas in the Brazilian amazon using MSI/Sentinel-2 imagery (2017). Remote Sens. 2018, 10, 1178. [CrossRef]

73. Kambey, J.L.; Farrell, A.P.; Bendell-Young, L.I. Influence of illegal gold mining on mercury levels in fish of North Sulawesi's Minahasa Peninsula, (Indonesia). Environ. Pollut. 2001, 114, 299-302. [CrossRef]

74. Rettberg, A.; Ortiz-Riomalo, J.F. Golden Opportunity, or a New Twist on the Resource-Conflict Relationship: Links Between the Drug Trade and Illegal Gold Mining in Colombia. World Dev. 2016, 84, 82-96. [CrossRef]

75. Vélez-Torres, I.; Méndez, F. Slow violence in mining and crude oil extractive frontiers: The overlooked resource curse in the Colombian internal armed conflict. Extr. Ind. Soc. 2021, 101017. [CrossRef]

76. Banda, W.; Chanda, E.K. A proposed cooperatives strategy for artisanal and small-scale gold mining sector in Zambia. Resour. Policy 2021, 70, 101909. [CrossRef] 